MATEC Web of Conferences 9, 02007 (2013)

DOI: $10.1051 /$ matecconf/20130902007

(C) Owned by the authors, published by EDP Sciences, 2013

\title{
Fire Safety in timber-based element façade-systems
}

\author{
Stefan Loebus ${ }^{a}$, Norman Werther and Stefan Winter
}

Technische Universität München Chair of Timber Structures and Building Construction

\section{INTRODUCTION}

As modernization of the existing building stock has become an important topic, there is a need for convenient retrofit solutions. The TES EnergyFaçade [1] offers a holistic approach based on timber framed prefabricated façade elements. Beside the requirements on structural aspects, building physics and durability, the fire safety of façade elements and of the entire structure must be considered in the design as well. This paper presents the design process and testing in respect to fire safety for timberframed façade elements, including fire engineering approaches and the conducted small scale and large scale fire tests.

\section{TES-FACADE}

The overall building stock accounts for more than 40 per cent of the primary energy demand of Europe. Due to this, almost $50 \%$ of the building stock is expected to undergo an energetic renovation. Especially the fraction built between 1948 and 1978, featuring a heating energy demand between 150 and $300 \mathrm{kWh} / \mathrm{m}^{2} \mathrm{a}$ [1]. Instead of demolishing, the more effective way is the retrofitting of the functional deficits of existing buildings in order to prepare them for low energy consumption and new necessities as communication and media connection or HVAC-installation (Heat, Ventilation and Air-Conditioning). The recently developed timber-based element system (TES) façade offers a convenient retrofit method to satisfy this demand (see Fig. 1). Key features are a high level of prefabrication, the use of natural and renewable building materials, and the possibility of adding special extensions or integrating service installations.

The principles of timber framing for the refurbishment of existing buildings are derived from the classic timber frame construction. The timber frames are usually constructed with sawn timber, gluelam or I-joists with studs in spacing of $625 \mathrm{~mm}-833 \mathrm{~mm}$ and an interior lining of OSB or plywood and a noncombustible mineral based board as external cladding. The cavities with a depth of up to $300 \mathrm{~mm}$ are fully filled with thermal insulation, such as cellulose fiber or mineral wool. Usually a timber-frame element measures about $12,0 \times 3,2 \mathrm{~m}^{2}$, limited by production facilities and transportation. [15]

Main field of application are multi-storey buildings, in which the use of timber-based façade products is quite new and fire safety requirements normally suited to non-combustible materials. As curtain wall system the TES-façade shall meet the requirements of an exterior wall, with separation function and those of a façade in addition, with limited flame spread at surface and no propagation of fires inside the elements or between the elements and the existing structure. For using combustible materials as substructure and preferably renewable combustible insulation materials closer examinations of the

ae-mail: loebus@tum.de

This is an Open Access article distributed under the terms of the Creative Commons Attribution License 2.0, which permits unrestricted use, distribution, and reproduction in any medium, provided the original work is properly cited. 


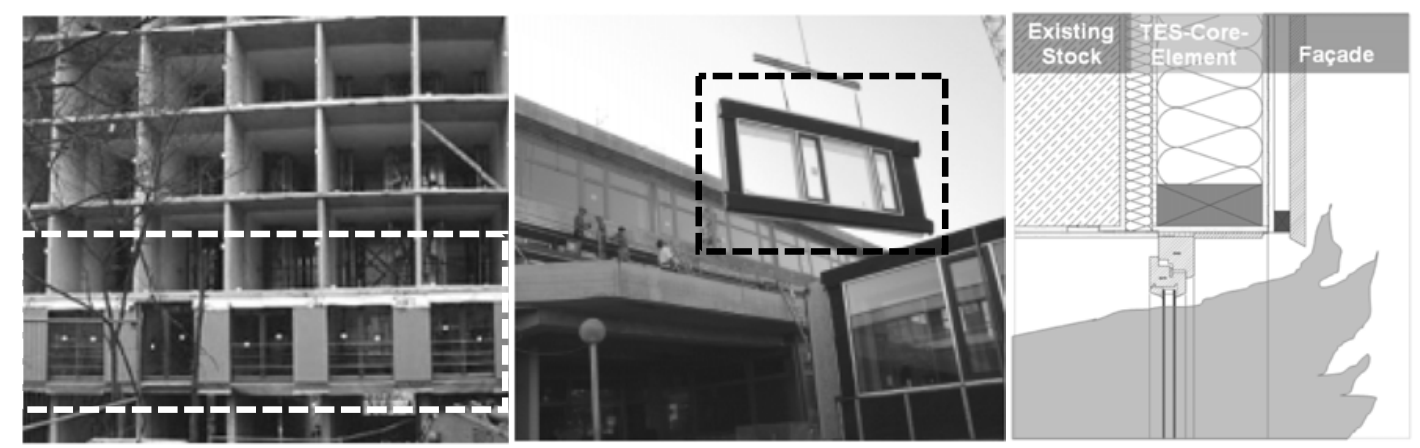

Figure 1. Mounting and Construction Section of a TES-façade.

TES-façade were necessary, to identify the potential risk of combustible materials in façade elements, to optimise the spatial elements, joints and junctions - and to meet the fire safety requirements finally.

\section{FIRE SCENARIOS}

Several fires in the last decades showed that occurrence of an external wall or façade fire may be attributed to one of the following three scenarios.

- ignition of the façade by radiation from an adjacent building fire or by flying brands,

- external exposure and ignition by e.g., burning of waste container or car fires close to the façade,

- ignition of the façade by external flaming out of a window in a post flash over compartment fire.

Due to the amount of available fuel in buildings with office or residential occupancy $\left(\mathrm{q}_{\mathrm{f}, \mathrm{k}(80)}=511-\right.$ $948 \mathrm{MJ} / \mathrm{m}^{2}$ [3]), the latter scenario generally represents the most critical condition to the façade, with hottest temperatures and longest duration of fire exposure. In ventilation controlled fires spilling flames out of a broken window with length of up to $4 \mathrm{~m}$ may occur. $[4,14]$

To ensure an appropriate level of safety without any negative influences of the TES-façade elements four scenarios/fire spread paths have been identified and investigated, as shown in Figure 2:

(1) separating function of the façade element itself and contribution to the fire resistance of the existing wall respectively

(2) fire penetration into the TES-Element and uncontrolled propagation inside the structure, exclusion of smouldering fires

(3) uncontrolled fire spread onto the façade and at the rear ventilation gap

(4) spread of flames, hot gases and smoke through the junctions of wall/TES element - floor.

The research work presented in this paper focuses on scenario no. 2 and 3. Those two scenarios depicted in Figure 2 are the most crucial to the TES façade system and essential to consider in the technical design process.

\section{DESIGN PROZESS FOR FIRE SAFETY}

The further investigations described herein are intended to determine the fire behaviour of the TES façade element (and façade cladding), exposed to heat and spilling flames of a fully developed ventilation controlled compartment fire, with excessive fuel burning outside the window.

Thus, in terms of thermal exposure the soffit area around the window opening is the most critical to the TES-façade. However, for this application the severity of exposure is not defined in general, by a European standard or testing regime and therefore in focus of the further investigation. 


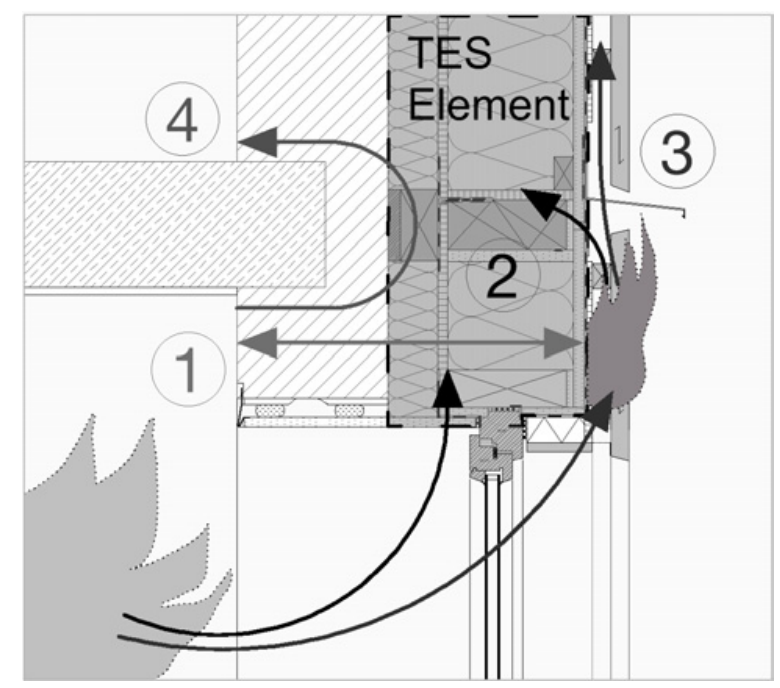

Figure 2. Fire safety objectives [7].

\section{Assessment of fire severity and determination of a design fire}

Based on fire tests $[6,9]$ and calculation methods, such as presented in standards or literature $[3,4]$, it is well known, that the temperature and heat flux along the façade decreases rapidly with increasing height above the window, due to the entrainment of ambient air. Structural members located outside of a burning compartment can be designed and tested for fire resistance with the external fire curve [3], unless they are engulfed in flames.

The exposed area around the window opening (soffit and upper parts of the reveals) is fully engulfed in flames, whereby the temperatures may assumed close to those inside the compartment [6,9]. The lower exposure in early stages of the fire, the reduced re-radiation of the compartment and the starting mixture of hot gases and fresh air in the post flash over phase only have a minor impact to the temperatures at the soffit and will be neglected in following calculation.

Based on the calculation method presented in Annex A and B of EN 1991-1-2 and the Zone model O-Zone [16] a parametrical study has been conducted to determine the temperatures inside the compartment and for the window soffit. The study considered the effects which various model parameters (opening factor, fuel load density, material of envelop, fire growth rate) may have on the temperatures in the compartment. Maximum opening factors for a ventilation controlled fire, fast and medium fire growth rates and fuel load density of office and residential buildings have been used to achieve high temperatures in the early phase of the fire. The maximum temperature in the derived design fire of TES façade elements is reached at the time when the fire services starts intervention, which for Germany can be assumed to be after 20 minutes fire exposure.

As shown in Figure 3a the exemplified parametric temperature time curve (black solid line) in the growth phase of a fire correspond well with soffit temperatures measured in full scale façade fire tests with a wood crib as fuel (dashed line) and for a propane gas burner fire (dotted line) respectively [5]. For comparison the external fire exposure curve (solid line with triangle marks) and the standard temperature/time curve of EN 1991-1-2 (solid line with circles) are depicted as well, which are commonly applied for most component tests regarding load-bearing and separating function.

The decay phase of the exposure is strongly influenced by the method and severity of fire service intervention. For further numerical simulation and design of the TES façade elements the duration of the decay phase was estimated conservatively to be the same as for the growth phase of the fire. 
a)

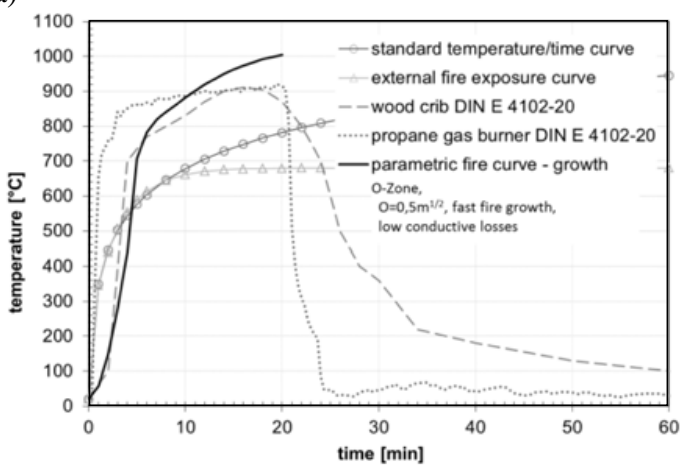

b)

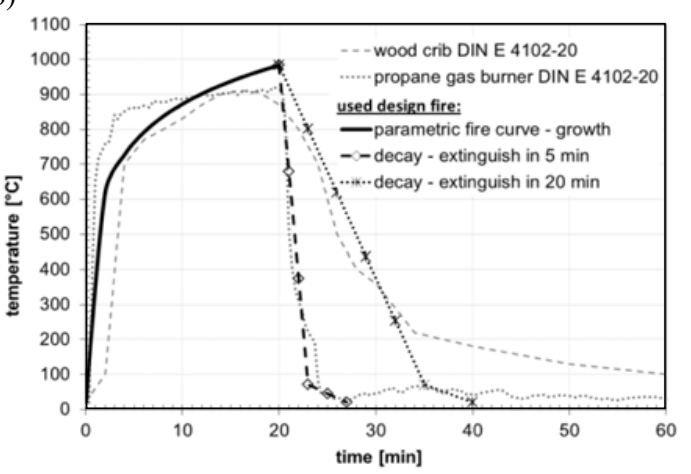

Figure 3. Derived temperatures for the soffit and comparison to full scale test result and standards. a) Comparison of temperature time curves. b) Used temperature time curve (design fire) in FE simulation.

Hence, after reaching the peak temperature, the curve declines to $20^{\circ} \mathrm{C}$ as a bi-linear function in 20 minutes and 5 minutes time respectively, as depicted in Figure $3 \mathrm{~b}$.

\section{FE-SIMULATION}

As described before the thermal exposure level for the window opening was derived from fire tests, fire engineering methods and under consideration of fire service callout time.

In further the pre-design - and detailing process of the façade elements numerical simulation (FE) were conducted to determine the appropriate dimension of the external lining.

In the simulations with the finite element software package Ansys [10] the entire external surface of the specimen was exposed to the derived fire curve of Figure $3 \mathrm{~b}$. The applied thermal exposure consisted of a radiative and convective fraction. As suggested in EN 1991-1-2, the emissivity $\varepsilon$ and convection coefficient $\alpha_{c}$ at exposed side were assumed equal to 0,8 and $35 \mathrm{~W} / \mathrm{m}^{2} \mathrm{~K}$, respectively. Material properties for timber, thermal insulation and gypsum fibre board were taken from EN 1991-1-2 and literature $[11,12]$ and implemented in the transient simulation.

The temperatures inside the specimen were measured at several points to assess critical condition in the growth and decay phase of the fire exposure.

The results of the simulation suggest a gypsum fibre board thickness of 15 to $18 \mathrm{~mm}$, to avoid an exceeding of critical temperatures of $200^{\circ} \mathrm{C}$ for combustible thermal insulation and $300^{\circ} \mathrm{C}$ for timber respectively [13].

\section{REAL FIRE EXPERIMENTS}

In the real fire tests the evaluations of exposure and preliminary FE-simulation were to be verified and adjusted. In comparison with existing test setups the behavior of the encasing cladding as main constructive measure against fire penetration was examined. Besides the encasing quality the tests gave an impression of the sensitiveness and behavior of timber and thermal insulation protected by the encasing cladding. Furthermore the protection capacity of joints in the encasing cladding at window lintel and at the junctions of elements was evaluated. On the basis of the evaluations of fire severity, preliminary FE-simulation, and relevant building materials the design of orientating small-scale fire tests was derived. From the small-scale test results and improved pilot project construction details the full-scale fire test was assembled and performed according to DIN E 4102-20. 

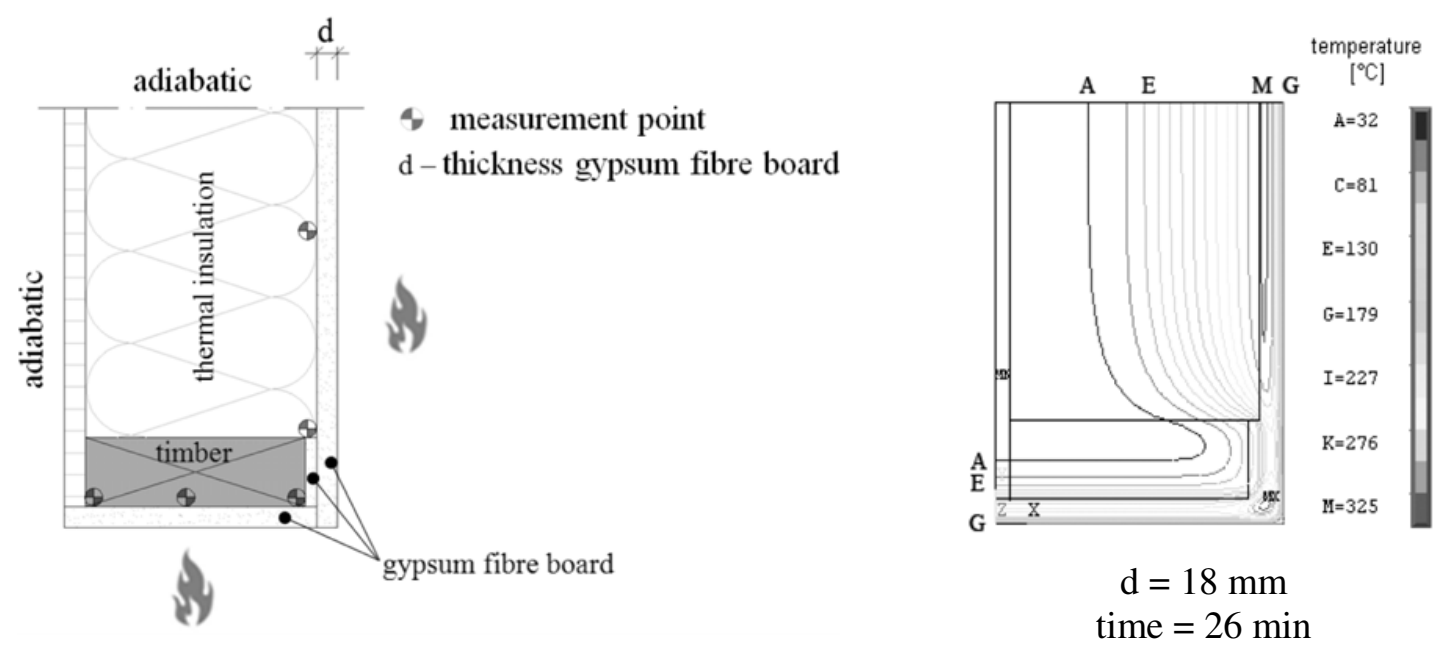

Figure 4. Modeling setup and isotherms at the time of 26 minutes.
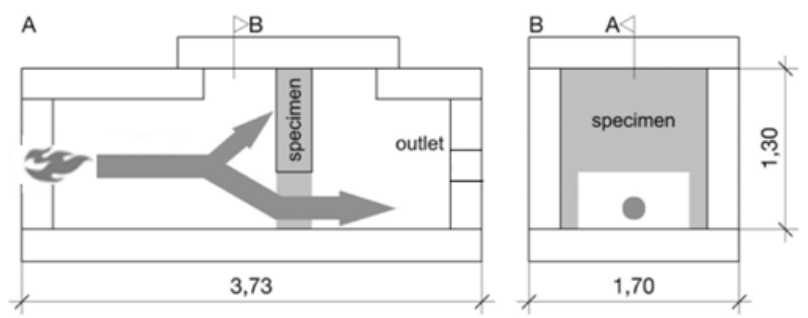

Figure 5. Furnace section - area of window opening [7].

\section{SMALL-SCALE TEST}

\section{Test setup}

This orientating test series resembles fire out of a window opening. To test the area above and next to the window a furnace as given Figure 5 was chosen as test stand. The specimen placed inside, is separated in a left and right side, offering two configurations per test. By coupling the diesel burner with thermal sensors the temperature in the furnace can be applied according to the parametric temperature curve as given in Figure 3. All specimens were exposed to that parametric temperature curve for 20 minutes followed by a cool down phase, in which fresh air was blown into the furnace (necessary to protect the diesel burner). Afterwards the specimen was lifted out of the furnace and extinguished with spraying water onto the surface. The further observation, with regards to smouldering fires inside the specimen took another 15 hours.

\section{Tested construction parameters}

Eight different construction designs (Table 1) were assessed with respect to - the protection capacity of encasing cladding, the occurrence of critical temperatures, the fire spread inside the elements and smouldering fires. Beside the spatial undisturbed area information on the influence of joints, junctions and fasteners were also gained. Different combustible timber-based thermal insulation materials were 
Table 1. Small scale fire tests - Relevant construction parameters [7].

\begin{tabular}{|c|c|c|c|c|c|c|c|c|}
\hline Test series & No. 1 & No. 2 & No. 3 & No. 4 & No. 5 & No. 6 & No. 7 & No. 8 \\
\hline $\begin{array}{l}\text { Thermal insulation } \\
\text { in-fill }\end{array}$ & $\begin{array}{l}\text { Cell. } \\
\text { fibre } 1\end{array}$ & $\begin{array}{l}\text { Cell. } \\
\text { fibre } 2\end{array}$ & \multicolumn{2}{|c|}{$\begin{array}{l}\text { Loose wood } \\
\text { fibre }\end{array}$} & $\begin{array}{c}\text { Mineral } \\
\text { wool }\end{array}$ & \multicolumn{3}{|c|}{$\begin{array}{l}\text { Wood } \\
\text { fibre }\end{array}$} \\
\hline $\begin{array}{l}\text { Thermal insulation } \\
\text { adaption layer }\end{array}$ & \multicolumn{2}{|c|}{$\begin{array}{l}\text { Cellulose } \\
\text { fibre } 1\end{array}$} & \multicolumn{6}{|c|}{ Mineral wool } \\
\hline $\begin{array}{l}\text { Encasing cladding } \\
\text { (gypsum fibre board ) }\end{array}$ & $15 \mathrm{~mm}$ & $15 \mathrm{~mm}$ & $15 \mathrm{~mm}$ & $18 \mathrm{~mm}$ & $15 \mathrm{~mm}$ & $18 \mathrm{~mm}$ & $\begin{array}{c}10 \mathrm{~mm} \\
\text { (front only) }\end{array}$ & $\begin{array}{c}10 \mathrm{~mm} \\
\text { (front only) }\end{array}$ \\
\hline ETICS & \multicolumn{6}{|c|}{ - } & $\begin{array}{c}\text { ETICS } 1 \\
\text { (Wood fibre) }\end{array}$ & $\begin{array}{c}\text { ETICS } 2 \\
\text { (Wood fibre) }\end{array}$ \\
\hline $\begin{array}{l}\text { Continuous or } \\
\text { separate encasing in } \\
\text { reveal and soffit area }\end{array}$ & \multicolumn{4}{|c|}{ Continuous } & \multicolumn{4}{|c|}{ Separate } \\
\hline
\end{tabular}

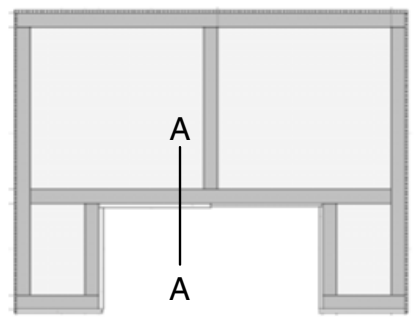

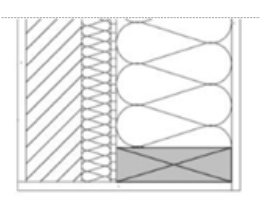

No. $1,2,3,4$

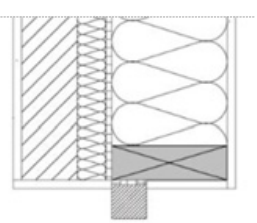

No. 5,6

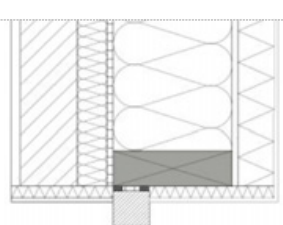

No. 7,8

Figure 6. Test specimen and variants in section A-A (Numbering according to Table 1).

compared to each other and to non-combustible stone wool. The loose wood fibre and the cellulose fibre insulation were blown-in materials. As the ignition behavior of the combustible thermal insulation materials varies, both the $15 \mathrm{~mm}$ and $18 \mathrm{~mm}$ thick gypsum fibre boards were considered as encasing cladding. Additionally two different wood-fibre-based ETICS (External Thermal Insulation Composite Systems) were tested. Another assessed parameter was the jointing detail of the window frame to the TES-element and the issue, if there is a difference between a continuous encasing cladding (see Fig. 6, No. 1-4) and one that is separated by a combustible timber window frame.

\section{Test Results}

\section{External thermal insulation composite system (ETICS) (No. 7, 8 in Table 1)}

Both systems of the specimen were penetrated by fire within the 20 minutes of fire impingement. During the further observation a combination of smouldering fire and visible burning within the ETICS overcame the rear $10 \mathrm{~mm}$ thick gypsum fibre board and ignited the wood-fibre insulation in the TESelement. In spite of heavy watering the ETICS a continuous re-ignition occurred. As a conclusion of those results wood-fibre boards cannot be recommended for an ETICS applied on a TES-element with fire safety requirements in higher building classes.

During the fire-impingement neither the $15 \mathrm{~mm}$ gypsum fibre board nor the $18 \mathrm{~mm}$ gypsum fibre board showed any relevant cracks in their surface. The temperature behind the $18 \mathrm{~mm}$ gypsum fibre board stayed below $150{ }^{\circ} \mathrm{C}$, while the temperature behind the $15 \mathrm{~mm}$ gypsum fibre board exceeded $350{ }^{\circ} \mathrm{C}$ in the area of cavity insulation. Temperatures around $350^{\circ} \mathrm{C}$ for a short period of time were acceptable for the cellulose fibre; if the oxygen supply was kept low. At the end of the fire impingement the temperature behind the $18 \mathrm{~mm}$ gypsum fibre board was significantly lower than behind the $15 \mathrm{~mm}$ gypsum fibre board (up to $200 \mathrm{~K}$ ). In the cool down phase the quick drop in temperature caused both 
Plain encasing cladding with gypsum fibre boards (No. 1-6 in)

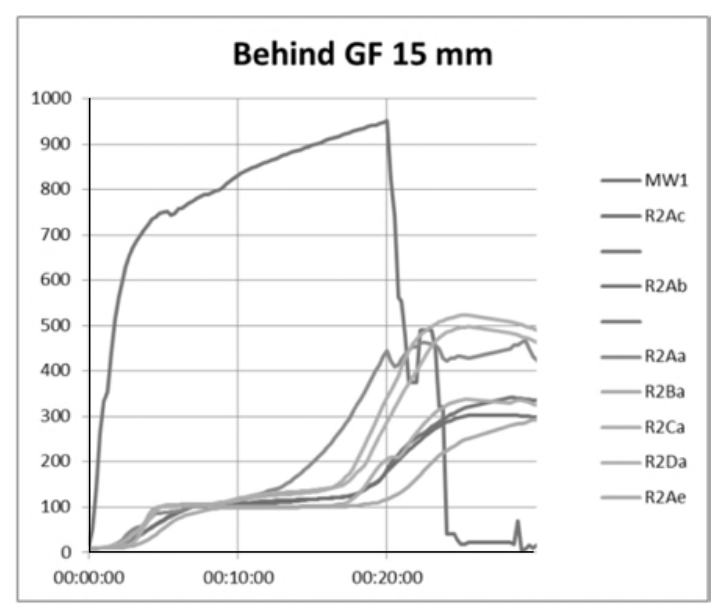

(a) $15 \mathrm{~mm}$

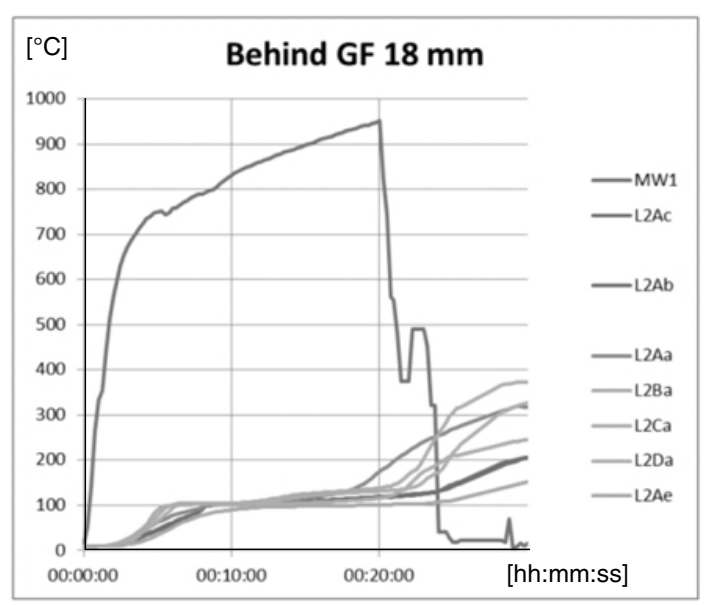

(b) $18 \mathrm{~mm}$

Figure 7. Time-temperature curve showing temperature rise behind the encasing gypsum-fiber boards (GF) for $15 \mathrm{~mm}$ (left) and $18 \mathrm{~mm}$ (right) thickness. MW1 describes the temperature in the furnace.

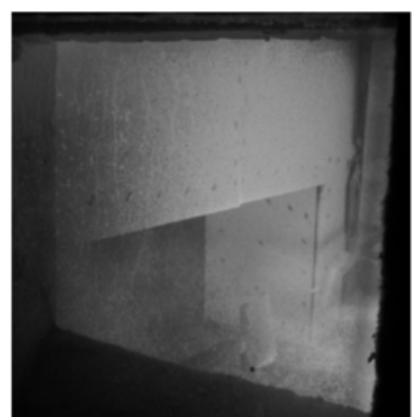

(a) in the furnace

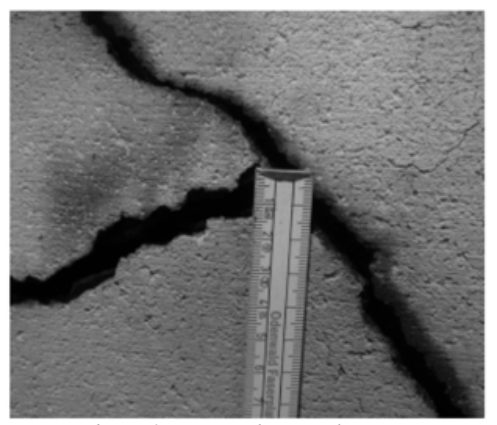

(b) after cooling phase

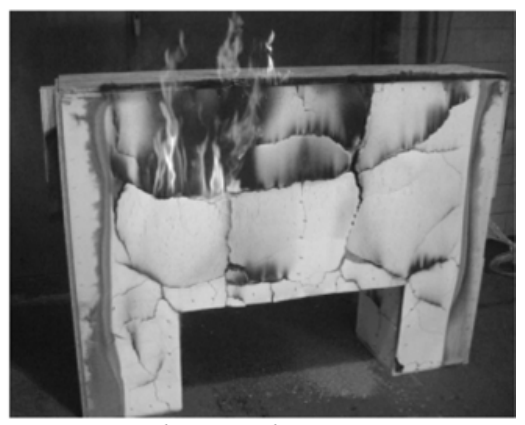

(c) during observation

Figure 8. Crack development in gypsum fibre board $(15 \mathrm{~mm})$.

types of gypsum fibre boards to crack widely (up to $12 \mathrm{~mm}$ ). Hereby the cracks in the $18 \mathrm{~mm}$ gypsum fibre board were less permeable than those in the $15 \mathrm{~mm}$ gypsum fibre board.

In the reveal and soffit area (except the lintel-corner) the temperature for the timber members did not rise above $350^{\circ} \mathrm{C}$ behind the $15 \mathrm{~mm}$ thick gypsum fibre board and not above $150{ }^{\circ} \mathrm{C}$ behind the $18 \mathrm{~mm}$ thick gypsum fibre board. At the lintel-corner several penetrations of fire through butt jointed gypsum fibre boards were observed.

The applied butt-joint between the gypsum fibre boards in the soffit/lintel was insufficient. So the constant supply with oxygen by cracks in the $15 \mathrm{~mm}$ gypsum fibre boards and opened joints in the soffit/lintel area, promoted by gaps in the thermal insulation, caused a chimney-effect and kept a smouldering fire alive.

The products of wood- and cellulose fibres were all vulnerable to smouldering fires. A precise filling, a reduced temperature impact, and the prevention of the chimney-effect can decrease this vulnerability. Contrary to the previous results the cellulose-filled specimen with an encasing cladding of $18 \mathrm{~mm}$ gypsum fibre board performed well. In all readings of the thermocouples the temperature declined from 


\section{MATEC Web of Conferences}

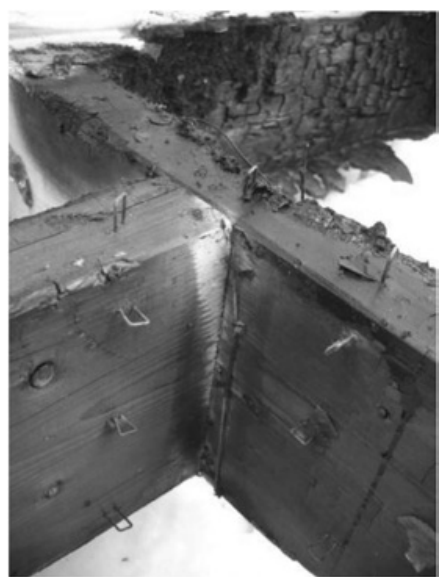

(a) $15 \mathrm{~mm}$

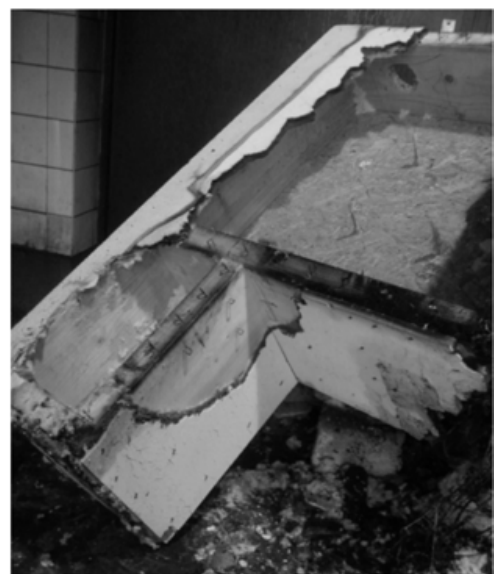

(b) $18 \mathrm{~mm}$

Figure 9. Charred timber behind the 15 and $18 \mathrm{~mm}$ gypsum fibre boards in the reveal.

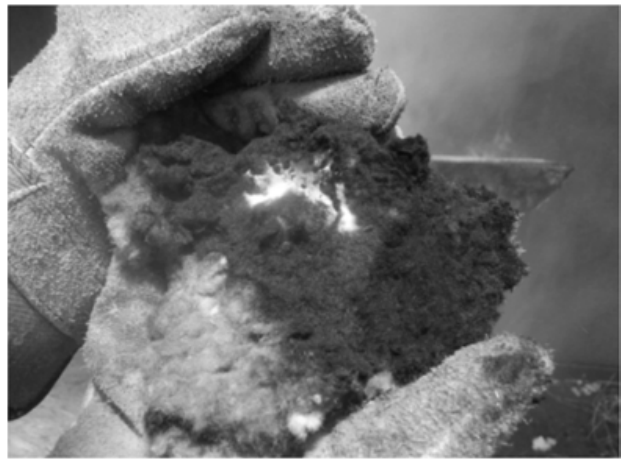

Figure 10. Smouldering of loose wood fibre.

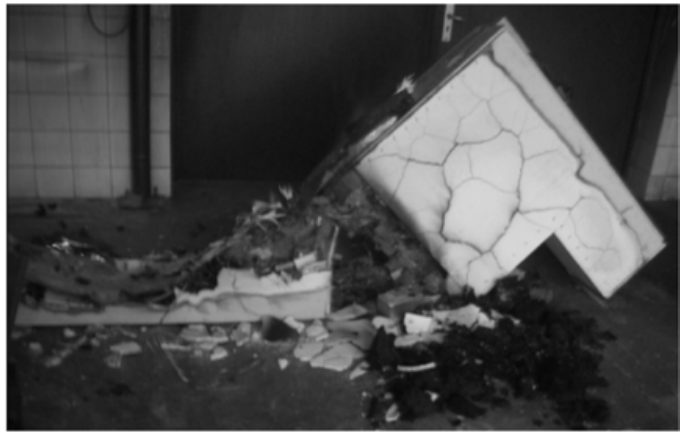

Figure 11. Small-scale fire test with loose wood fibre and gypsum fibre boards in $15 \mathrm{~mm}$ (left) and $18 \mathrm{~mm}$ (right) after 15 hours of observation.

$350{ }^{\circ} \mathrm{C}$ to $50^{\circ} \mathrm{C}$ while observing. A direct ignition of the equalizing-layer filled with mineral wool or cellulose through the soffit was not detected. As conclusion of the small-scale tests follows, that the applied exposure can cause fire spread inside the elements which is difficult to detect and to extinguish. Main reasons are an insufficient dimension of the encasing cladding, detailing of the joints, gaps and void cavities. Comparing the temperatures in the specimen, the results of the FE-Simulation have partly been proven. As a consequence of the results for the further tests an $18 \mathrm{~mm}$ thick gypsum fibre board was recommended. To prevent fire penetration through the joints in the soffit/lintel area each gypsum fibre board-joint has to be back-blocked with an extra layer of gypsum board, especially in the thermal highly-exposed lintel-corner.

\section{LARGE-SCALE REAL FIRE TEST}

\section{Tested construction parameters}

Based on the results of the small-scale fire tests to the window opening, the construction of the largescale test was assembled as summarized in Table 2: 
Table 2. Large scale fire tests - Relevant construction parameters [7].

\begin{tabular}{|l|c|}
\hline Test series & No. 1 \\
\hline Thermal insulation in-fill & Cellulose fibre 2 \\
\hline Thermal insulation adaption layer & Cellulose fibre 2 / mineral wool in window area \\
\hline Encasing cladding (gypsum fibre board ) & $18 \mathrm{~mm}$ thick \\
\hline Construction Jointing of encasing cladding & Deposit of 10 $\mathrm{mm}$ thick stripe gypsum fibre board \\
\hline Façade cladding & - \\
\hline $\begin{array}{l}\text { Continuous or separate encasing cladding } \\
\text { in reveal and soffit area }\end{array}$ & Continuous \\
\hline
\end{tabular}

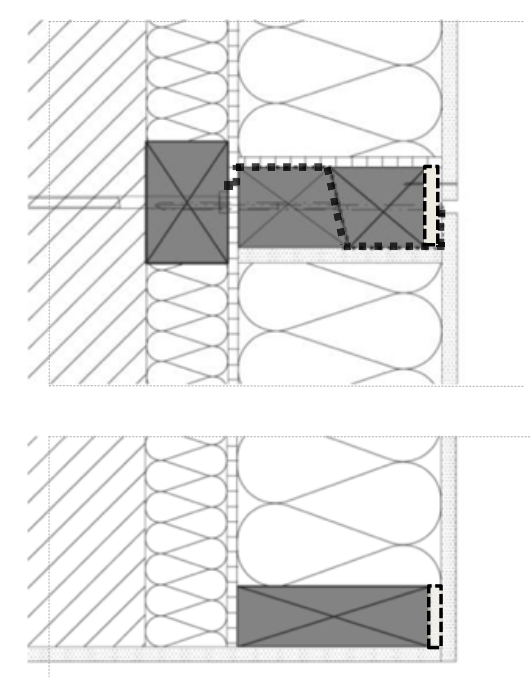

(a) Vertical section

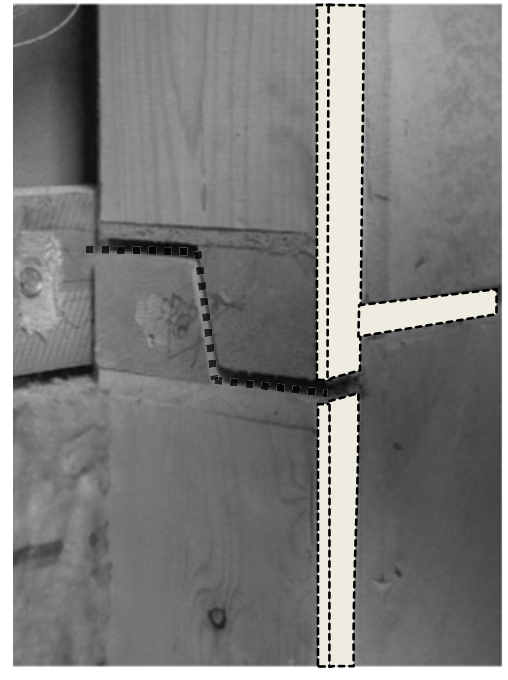

(b) Specimen element piece

Figure 12. Gypsum fibre board backing in element joint and window lintel.

The TES-Façade is produced in a high prefabrication level often with a fully mounted façade cladding. Therefore the encasing cladding behind is hardly reachable for further onsite work (see detailing in Figure 14c). Furthermore the gap in the element joint zone can barely be closed by applying conventional gypsum board gluing. Therefore the joint of two elements was backed by an additional stripe of gypsum fibre board (see Fig. 12). The same method was used at the lintel corner, to create a step joint, as a consequence from fire penetration in the small-scale tests.

The TES-element was tested in plain without any application of façade cladding. This results in an eminent fire exposure reflecting the worst case. Further the results of this real fire test can be combined with otherwise conducted full scale fire tests on façade cladding as described later in the text.

\section{Test procedure}

The test approach corresponds to DIN E 4102-20 [2] "special proof for the fire performance of external walls" as part of a draft standard of the German Institute for Building Technology. The test stand is an outside wall in natural scale with a nook, on which the façade system specimen is mounted in its original state (see Fig. 13). A gas burner exposes the specimen thermally under natural ventilation conditions. As defined for flame retardant façade systems/materials, the exposure time is 20 minutes [8]. 


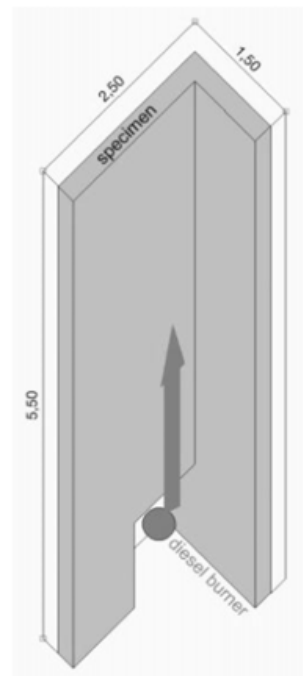

(a) Testing setup

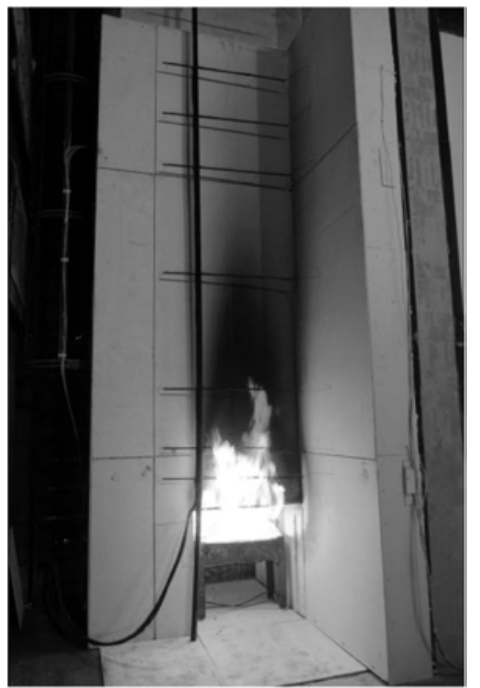

(b) While testing

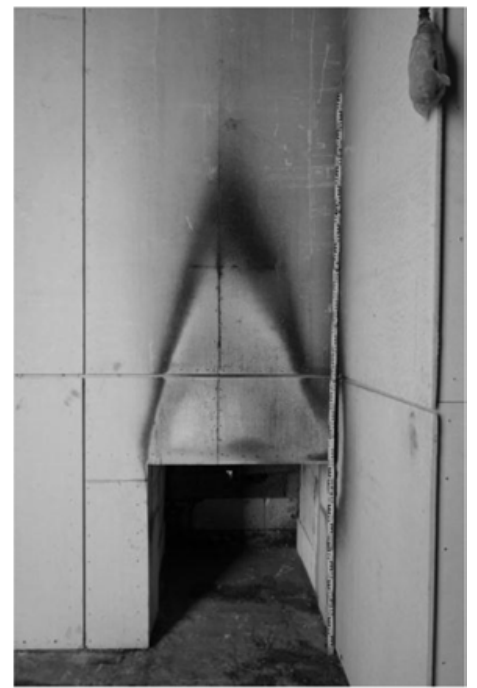

(c) After the test

Figure 13. Exterior wall test setup.

\section{COMBINATION OF RESULTS - APPLYING A WOODEN CLADDING}
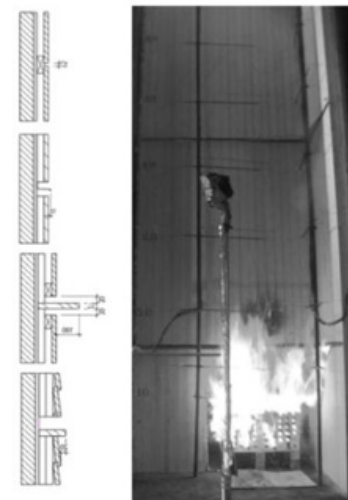

(a) Samples of façade claddings examined in real fire tests [5]

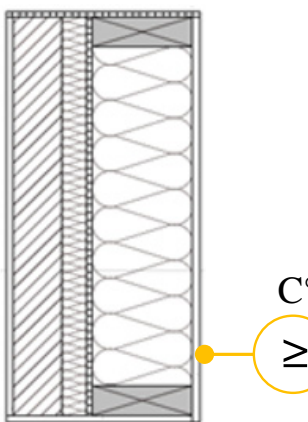

Specimen TES-Element

(b) Comparison of temperature exposure [6]

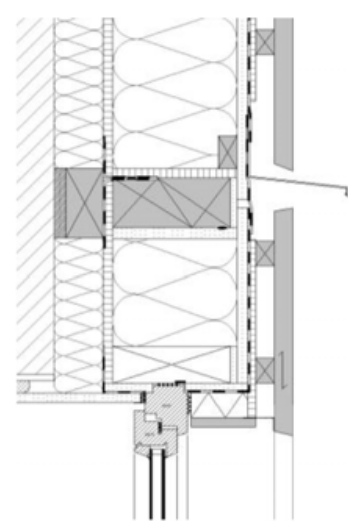

(c) Complete TESFaçade Detail

Figure 14. Combining test results.

\section{Test results}

Over the 20 minutes time of fire exposure and beyond no damage like cracks in the gypsum fibre board surface were reported. After the shutdown of the gas burner and in the following observation phase of roughly 20 hours no smouldering fire or visible burning occurred. The quick cooling down of the specimen surface through watering immediately after the shutdown of the gas burner with a spray jet from a fire hose did not cause any recognizable damage like cracking of the gypsum fibre boards, as it happened in the small-scale fire tests. Parts of the gypsum fibre board were removed and the elements 
$1^{\text {st }}$ International Seminar for Fire Safety of Facades, Paris (France), 2013

dismantled. Neither on the timber elements nor on the thermal insulation material in the elements and the adaption layer fire damage was recognizable.

\section{COMBINATION OF RESULTS - APPLYING A WOODEN CLADDING}

For the application of combustible claddings research and testing was conducted in [5]. Twenty-eight different wooden façade claddings varying in fire stops, façade material und substructure were tested in a large-scale fire testing setup on a non-combustible wall surface - similar to the conducted large-scale test presented herein. The temperatures behind the façade cladding and on the surface of the TES-element were recorded geometrically in the same locations. Comparing both temperature exposures with each other each type of wooden façade cladding can be applied if its recorded temperature stays below the temperature recorded on TES-element over the entire testing period (Fig. 14c) [7].

\section{CONCLUSION}

With regards to the proposed design fire, the standard for fire exposed curtain walling and façade claddings need to be discussed further and harmonised in Europe. Comparing the exposure level of the conducted small- and large scale tests the results vary regarding applicability of materials and design. The tests showed clearly the influence of thickness of the encasing cladding to the fire safety and the consequence of insufficient designed joints and junctions in combination with combustible insulation materials. As result of the conducted examination, practical solutions for a fire safe design of prefabricated TES-façades were developed and are available now. An application of TES in Building class 4 and 5, in accordance with the German Model Building Regulation is feasible. In further tests the spread of flames, hot gases and smoke through the junctions of wall/TES element - floor as depict in Figure 2 No. 4 have been examined and will be evaluated in ongoing research work.

\section{References}

[1] TES EnergyFaçade - prefabricated timber based building system for improving the energy efficiency of the building envelope. http://www.tesenergyfacade.com. Period from 01/2008 to 12/2009, funded by BMBF, represented by PTJ.

[2] DIN E 4102-20 - "Brandverhalten von Baustoffen und Bauteilen - Besonderer Nachweis für das Brandverhalten von Außenwandbekleidung", Fassung März 2010

[3] DIN EN 1991-1-2: Actions on structures - Part 1-2: General actions - Actions on structures exposed to fire, December 2010

[4] SFPE Handbook of Fire Protection Engineering, 4th edtion, National Fire Protection Association, 2008

[5] HTO Research Report HTO TP2 (High-Tech-Offensive Bavaria, Subproject 2), Brandsicherheit im mehrgeschossigem Holzbau, TU München 2009

[6] HTO Research Report HTO TP 11 (High-Tech-Offensive Bavaria, Subproject 11), Mechanismen der Brandweiterleitung bei Gebäuden in Holzbauweise, TU München 2009

[7] smartTES. Period from 10/2010 to 209/2013, funded by BMBF, represented by PTJ, Finalreport to be pulished in September 2013

[8] Research Report No. UB 3.3/11-032-1, MFPA Leipzig, June 2012, unpublished

[9] Cheng, H., Hadjisophocleous, G. V.: Experimental study and modeling of radiation from compartment fires to adjacent buildings, ELSEVIER, Fire Safety Journal 53 (2012) page 43-62,

[10] ANSYS version 12.0 ANYS Inc., Canonsburg, PA, USA, 2009

[11] Schleifer, V.: Zum Verhalten von raumabschließenden mehrschichtigen Holzbauteilen im Brandfall, PhD thesis; ETH Zürich 2009 


\section{MATEC Web of Conferences}

[12] Meyn, W.: Experimentelle und numerische Analyse des thermischen sowie Grundlagen des strukturmechanischen Verhaltens von Holzrahmenwänden bei thermischer instationärer Einwirkung unter Berücksichtigung des nichtlinearen Materialverhaltens. 1.Aufl. Berlin: dissertation.de - Verlag im Internet GmbH 2009, Dissertation Universität Leipzig, 2008

[13] Hosser, D., Kampmeier, B.: Anwendung brennbarer Dämmstoffe im mehrgeschossigen Holzbau Ernst \& Sohn Verlag GmbH \& Co. KG, Berlin, 2007

[14] Kotthoff, I.: Glasfassaden - Brandausbreitung an Fassaden; VI. Baurecht \& BrandschutzSymposium; Frankfurt am Main, 2002

[15] Ott S, Loebus S, Winter S.: Vorgefertigte Holzfassadenelemente in der energetischen Modernisierung. in: Bautechnik, DOI: 10.1002/bate.201330024. 2013. vol 90 (1), pp 26-33.

[16] Cadorin, J.F., Pintea, D., Franssen, J.M.: Ozone V2.2, University of Liege, 2009 